\title{
SEMATOPHYLLUM (SEMATOPHYLLACEAE, BRYOPHYTA), A NEW GENUS AND FAMILY FOR RUSSIA

\author{
SEMATOPHYLLUM (SEMATOPHYLLACEAE, BRYOPHYTA) -
} НОВЫЕ РОД И СЕМЕЙСТВО ДЛЯ РОССИИ
}

\author{
E.A. IGNATOVA ${ }^{1}$, B.C. TAN ${ }^{2}$, O.M.AFONINA ${ }^{3} \&$ M.S.IGNATOV ${ }^{4}$ \\ Е.А. ИГНАТОВА ${ }^{1}$, Б.Ч. ТАН ${ }^{2}$, О.М.АФОНИНА ${ }^{3}$, М.С. ИГНАТОВ ${ }^{4}$
}

Abstract

Sematophyllum substrumulosum (Hampe) E. Britton found as a new species record for Russia in Zabaikalsky Territory in Eastern Siberia, ca. $8000 \mathrm{~km}$ from its nearest localities in Southern Europe. This is the first record of the genus, as well as the family Sematophyllaceae, s. str. (excluding Pylaisiadelphaceae) from Russia. Interestingly, this species known in the Mediterranean region in temperate climate is found in Russia in mountain tundra in extremely cold environment. Description, illustrations and phytogeographical considerations are given.

Резюме

Sematophyllum substrumulosum (Hampe) Е. Britton найден ввервые в России, в Забайальком крае. Данное местонахождение удалено от ближайших точке в Южной Европе (Хорватия) на примерно 8000 км. Данная находка является первой для России как для рода Sematophyllum, так и для семейства Sematophyllaceae в совеременном его понимании (исключая Pylaisiadelphaceae). Интересно, что будучи приуроченным к мягкому и теплому климату Средиземноморья, этот вид растет в Сибири в регионе сплошного распространения вечной мерзлоты и, к тому же, в высокогорьях. Приводится описание и иллюстрации вида, а также обсуждение его фитогеографии.

KEYWORDS: Sematophyllum, Sematophyllaceae, Bryophyta, disjunction, phytogeography

\section{INTRODUCTION}

The South Siberian mountains are diverse and interesting phytogeographycally, and it has been shown to be refugia rich in isolated population of a number of temperate species, growing under severe boreal climatic conditions. These relict species largely belong to either East Asiatic elements (Anomodon thraustus, Forrstroemia noguchii, Homomallium connexum), or East Asiatic-eastern North American elements (e.g. Brothera lea- na, Buxbaumia minakatae, Anomodon minor, Entodon challengeri, Syntrichia amphidiacea, Lindbergia brachyptera), or widespread tropical species more common in eastern parts of Asia and North America (Herpetineuron toccoae, Hyophila involuta, Heterophyllium affine, Haplocladium microphyllum) [nomenclature follows Ignatov, Afonina, Ignatova et al., 2006]. Only a few temperate western Palearctic species are known in this area: Homalothecium philippeanum, Neckera bes-

1 - Biological Faculty, Moscow State University, Moscow 119991 Russia - Россия 119991 Москва, Московский государственный университ, Биологический факультет, каф. геоботаники.

2 - Singapore Botanic Gardens, 1 Cluny Road, 259569 Singapore and Department of Biological Science, National University of Singapore, Science Drive 4, Singapore, 119260

3 - V. L. Komarov Botanical Institute Rus. Acad. Sci., Prof. Popov Str., 2, St. Petersburg, 197376 Russia Россия 197376, Санкт-Петербург, ул. Проф. Попова, 2, Ботанический институт им. В. Л. Комарова PAH; e-mail: stereodon@yandex.ru

4 - Main Botanical Garden, Russian Academy of Sciences, Botanicheskaya 4, Moscow 127276 Russia, e-mail: misha_ignatov@list.ru 
seri, Cinclidotus riparius, Orthotrichum vladikavkanum, and most of them reach only Atlai and Western Sayan Mts., the western part of this area, and do not penetrate further eastward.

Under this circumstances, the recent finding of a species of Sematophyllum in the area east of Baikal Lake, has logically made us to look for its identity among the East Asiatic species. However, after an expanded search, it was found to belong to a species of the Mediterranean flora, $\mathrm{Se}$ matophyllum substrumulosum. The discovery was very unexpected, as this species is a rare one and have a distribution, which can be considered to have a rather narrow range for the holarctic mosses. The species is known at present from Macaronesia (Canary Islands, Azores and Madeira), in Mediterranean Europe ranging from Portugal and Spain to Croatia, and from Algeria and Morocco in North Africa (Düll, 1985; Düll et al., 1999; Hedenäs, 1992; Ros et al., 1999). The present Transbaikalian locality in Zabaikalsky Territory of Russia has a geographical distance from the Croatia for ca. $8000 \mathrm{~km}$. Moreover, in Europe this species prefers a rather temperate environment, at least it is not known in high mountains, while in Siberia it was collected at $1997 \mathrm{~m}$ elev. in mountain tundra in the area with the continuous permafrost, and the mean annual temperature $3^{\circ} \mathrm{C}$ below zero even at the lowest elevation (ca. $700 \mathrm{~m}$ ). The paper of Afonina (2009) on the moss flora of that area can be consulted for additional information of the local conditions.

Nevertheless, comparison with moss collections from South Europe and Macaronesia demonstrates that the Siberian specimen has no single morphological character that falls outside the range of variation of characters of the European plants, thus, its identification is rather certain, even without sporophytes.

Sematophyllum substrumulosum (Hampe) E. Britton, J. Bot. 40: 354. 1902. - Hypnum substrumulosum Hampe, Bot. Zeitung (Berlin) 20: 12. 1862. - Fig. 1.

Plants small, in slender mats, yellowishgreen, glossy. Stems 1.0-1.5 cm long, 2.5-3.0 mm wide with leaves, brown, fragile, irregularly branched, densely to moderately distantly foliose. Stem leaves erecto-patent to spreading when dry and wet, easily detached, from oblong base rather abruptly narrowed into long narrow acumen, rounded to base, $1.5-2.0 \times 0.3-0.4(-0.5) \mathrm{mm}$, concave proximally, plane distally, margins minutely crenulate from apex to mid-leaf, subentire at leaf base, plane; costa double, short or indistinct; upper laminal cells 30-60×7-10 $\mu \mathrm{m}$, median laminal cells $(40-) 65-110(-130) \times 7-10$ $\mu \mathrm{m}$, linear, with narrow angles, thick-walled; cell walls slightly porose and especially incrassate near cell ends, which exhibit a tendency towards 'bone-shaped' pattern, although to a rather limited extend and apparent only in a few places; basal juxtacostal cells rectangular, with strongly thickened and strongly porose walls, orangebrown; alar cells 2-3 in one row, large, elongate, inflated, moderately thick-walled, orange-brown or pellucid, supra-alar cells few, subquadrate or short-rectangular, thick-walled, junction of alar and subpra-alar cells is rather fragile, and alar cells commonly remain attached to stem. Autoicous, both perigonia and unfertilized perichaetia seen. Sporophytes unknown in Russian plants.

Specimen examined: Southern Siberia, Zabaikalski Territory, Sokhondinski Reserve, Upper Bukukun River, $49^{\circ} 38^{\prime} \mathrm{N}, 111^{\circ} 03^{\prime} \mathrm{E}$, alt. 1997; summit area, $D r$ yas-Carex-lichen tundra. 17.VII.2008 O.M.Afonina \#04208 (LE, MHA).

Additional specimens were studied from Italy (Barsali, 10.I.1911, LE; Bottini, year 1898, LE), and Canaries (Townsend 78/275).

Among Asiatic species of Sematophyllum, the most similar to $S$. substrumulosum are $S$. subhumile (Müll. Hal.) M. Fleisch. and S. pulchellum (Cardot) Broth. as they also have long laminal cells at the leaf apex, while other species have shorter cells in distal part of leaves.

Sematophyllum pulchellum and S. subhumile differ in leaves being homomallous, 1.2-1.5 mm long, acute.

Sematophyllum subhumile subsp. japonicum (Broth.) Seki differ in smaller size, leaves more

Fig. 1. Sematophyllum substrumulosum (Hampe) E. Britton (from Russia, Afonina \#04208, LE): 1 - upper laminal cells; 2-3 - habit, dry; 4-8 - leaves; 9 - stem transverse section; 10-12 - median laminal cells; 13 - lower median laminal cells; 14 - basal laminal cells. Scale bars: $3 \mathrm{~mm}$ for $3 ; 2 \mathrm{~mm}$ for $2 ; 1 \mathrm{~mm}$ for 4-8; $100 \mu \mathrm{m}$ for 1, 9-14. 


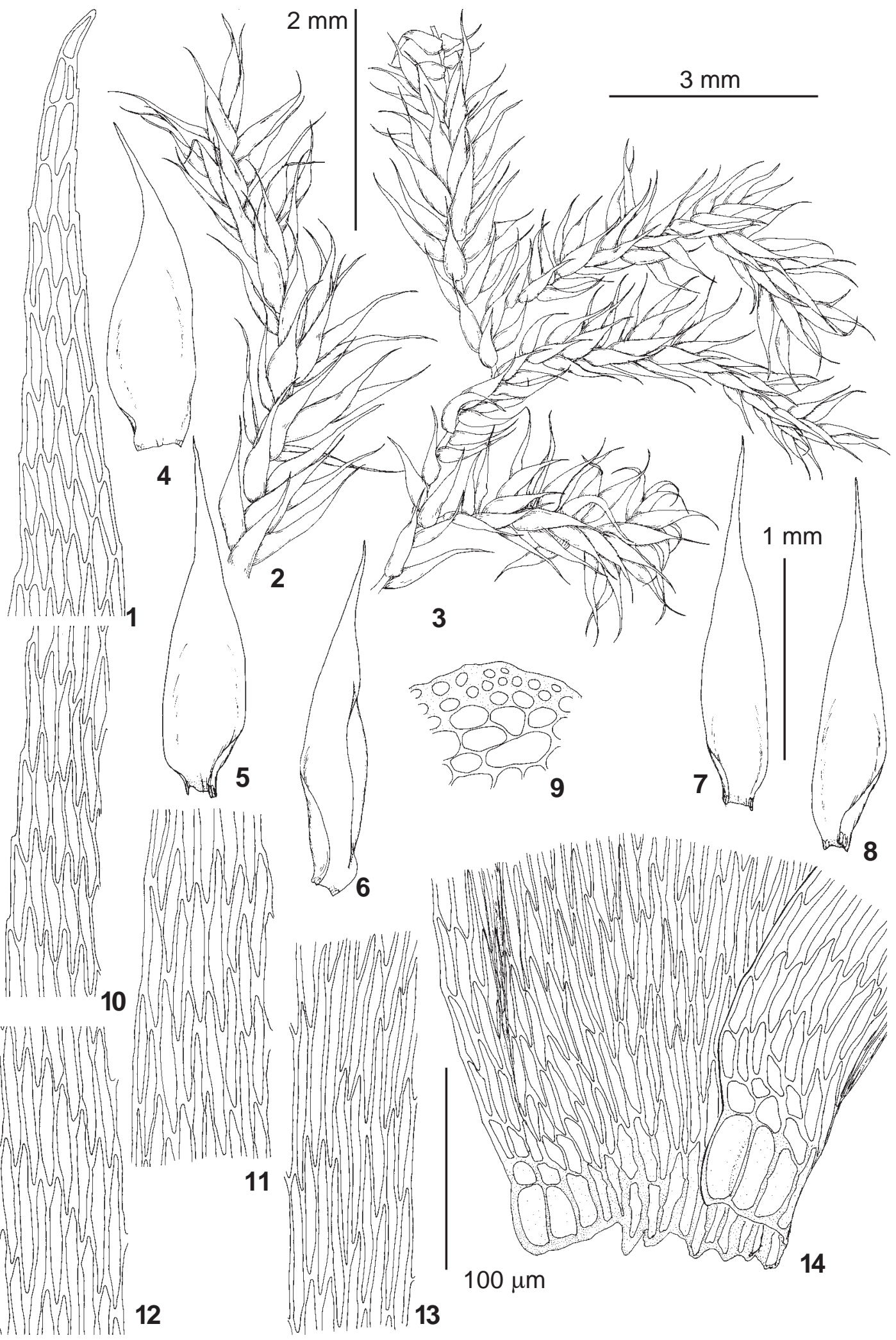


shortly acuminate; laminal cells thin-walled, and shorter, 55-75 $\mu \mathrm{m}$ long.

Phytogeographic considerations. It is very difficult to find a case of similar distribution in mosses like S. substumulosum. The closest parallel might be drawn by the comparison with Ctenidium molluscum. This European calciphilous species is especially common in the Mediterranean and Submediterranean regions. It occurs in Russia in abundance only in Caucasus, where it is very frequent in the Black Sea coast, but rare in more inland areas. In addition to this, it is known in European Russia only in Karelia (Eastern Fennoscandia), in one limited place in calcareous area. It is totally absent in other parts of European Russia, and all records from Urals appear to be erroneous. However it was found in calcareous areas in Asiatic Arctic, in Yamal and Taimyr (Blagodatskikh, 1972; Czernyadjeva, 2001) and also in a few other places in Siberia within permafrost area, always in a very low abundance.

The present population of $S$. substrumulosum found in Zabaikalski Teritory may also indicate that the area in Eastern Siberia might had a warmer climate in the past like that found in present day Mediterranean region. This population in Russia is relictual and needs protection for its continued survival. Fortunately it is situated within the territiory of Strict Nature Reserve "Sokhondinsky" (Afonina, 2009).

$$
\text { * * * * }
$$

The family Sematophyllaceae was previously reported from Russia based on the species of genera Heterophyllium, Brotherella and Pylaisiadelpha. The recent phylogenetic studies (e.g. Tsubota et al., 2004; Arikawa, 2008), however, demonstrated that the family in its traditional circumscription should be split into two. One of them, Pylaisiadelphaceae, includes all the genera previously known in Russia, thus, Sematophyllaceae was excluded from the country (Ignatov, Afonina, Ignatova et al., 2006). With the present discovery of $S$. substrumulosum in Eastern Siberia, the family Sematophyllaceae will need to be included again in the Russian moss flora.

The family Sematophyllaceae sensu stricto is mostly a tropical and subtropical one. Plants are characterized by ecostate leaves, a usually strongly modified peristome, absence of any foliose structures ('pseudoparaphyllia') on stems around dormant buds, and strongly enlarged alar cells.

\section{ACKNOWLEDGEMENTS}

The work was partly supported by The Programm "Biodiversity" of Russian Academy of Sciences and RFBR 07-04-00013.

\section{LITERATURE CITED}

AFONINA, O.M. 2009. On moss flora of the Sokhondinsky State Nature Biosphere Reserve (Zabaikalsky Territory). Arctoa 18: 141-150.

ARIKAWA, T., H. TSUBOTA, H. DEGUCHI, N. NISHIMURA \& M. HIGUCHI 2008. Phylogenetic analysis of the family Hypnaceae based on rbcL gene sequences. - In: H.Mohamed, B. H. Bakar, A. N. Boyce \& P. Lee (eds). Bryology in the New Millennium, Kuala-Lumpur, University of Malaysia. 2008. pp. 215-225.

[BLAGODATSKIKH, L.S.] БЛАГОДАТСКИХ Л.С. 1972. К бриофлоре Западного Таймыра. - [On bryoflora of the Western Taimyr] Новости сист. низи. pacm. [Novosti Sist. Nizsh. Rast.] 9: 358-364.

CZERNYADJEVA, I.V. 2001b. Moss flora of Yamal Peninsula (West Siberian Arctic). - Arctoa 10: 121-150.

DÜLL, R. 1985. Distribution of the European and Macaronesian mosses (Bryophytina), 2. - Bryol. Beitr. 5: 110-232.

DÜLL, R., A. GANEVA, A. MARTINCIC \& Z. PAVLETIC 1999. Contributions to the bryoflora of the former Yugoslavia and Bulgaria. - IDH-Verlag Bad Münstereifel. 5: 199.

HEDENÄS, L. 1992. Flora of Madeiran pleurocarpous mosses (Isobryales, Hypnobryales, Hookeriales). - Bryophyt. Biblioth. 44. $165 \mathrm{pp}$.

IGNATOV M.S., AFONINA O.M., IGNATOVA E.A., A. ABOLINA, T.V. AKATOVA, E. Z. BAISHEVA, L.V. BARDUNOV, E.A. BARYAKINA, O.A. BELKINA, A.G. BEZGODOV, M.A.BOYCHUK, V.YA. CHERDANTSEVA, I.V. CZERNYADJEVA, G.YA. DOROSHINA, A.P. DYACHENKO, V.E. FEDOSOV, I.L. GOLDBERG, E.I. IVANOVA, I. JUKONIENE, L. KANNUKENE, S.G. KAZANOVSKY, Z.KH. KHARZINOV, L.E. KURBATOVA, A.I.MAKSIMOV, U.K. MAMATKULOV, V. A. MANAKYAN, O.M. MASLOVSKY, M.G. NAPREENKO, T. N. OTNYUKOVA, L.YA. PARTYKA, O.YU. PISARENKO, N.N. POPOVA, G.F. RYKOVSKY, D.YA. TUBANOVA, G.V. ZHELEZNOVA, V.I. ZOLOTOV 2006 [2007]. Check-list of mosses of East Europe and North Asia. - Arctoa 15: 1-130.

ROS, R. M., M. J. CANO \& J. GUERRA 1999. Bryophyte checklist of Northern Africa. - J. Bryol. 21: 207-244.

TSUBOTA, H., E. DE LUNA, D. GONZALEZ, M.S.IGNATOV \& H. DEGUCHI 2004. Molecular phylogenetics and ordinal relationships based on analyses of a largescale data set of $600 \mathrm{rbcL}$ sequences of mosses. - Hikobia 14: $149-170$. 